\title{
Experiences of Intellectually Gifted Students in an Egalitarian and Inclusive Educational System: A Survey Study
}

\author{
Roland S. Persson \\ Jönköping University, Sweden
}

A study was launched in an educational setting where giftedness is not officially recognized to explore intellectually gifted students' experience of family background and support, their age and means of identification, the degree of support received in school, and the understanding they experienced from a primary to a tertiary education level. In all, 287 members of the Swedish branch of Mensa (216 men and 71 women), all with IQ scores equal to or higher than the 98th percentile, constituted the research group. A survey design was used and provided as an Internet-based questionnaire. Quantitative data were analyzed as within-group dispersions, whereas qualitative data were subjected to a straightforward content analysis. Results show cause for concern. In particular, primary school appeared to be a hostile environment. However, conditions improved somewhat as participants moved from primary to secondary school and again from secondary to tertiary education. However, the participants remained far from satisfied at any level of the education system. Four problem areas were identified in the study as constituting the gifted students' compounded dilemma in an egalitarian, regular, and inclusive school system.

In an international perspective, intellectually gifted individuals are often seen as "the hope of the future" (e.g., Wilms, 1986). It would seem only natural, then, to expect that educators in most school systems all over the world would be eager to assist their potentially high-achieving gifted students. Paradoxically, while providing special education for slow learners is never controversial, providing intellectual stimulation to the gifted learners is on occasion very controversial even at a tertiary level. Resistance to providing suitable education for students who need more, even much more, intellectual stimulation than the average student, is not uncommon (e.g., Howley, Howley, \& Pendarvis, 1995; Raina, 1996; Thompson, 1994; Winner 1996). The debate tends to focus on how to understand the idea of equity in a democracy (e.g., Borland, 2003; McDaniel, 2002). It is likely that nowhere is resistance to assist gifted students in school stronger than

Roland S. Persson is a professor of educational psychology at Jönköping University in Sweden.

Journal for the Education of the Gifted. Vol. 33, No. 4, 2010, pp. 536-569. Copyright (C2010 Prufrock Press Inc., http://www.prufrock.com 
in the Scandinavian countries for historical, cultural, and political reasons, particularly in Sweden (Englund, 2005; Persson, Balogh, \& Joswig, 2000), which makes studying gifted students in the educational system of Sweden particularly interesting.

There has been only limited research done on how gifted learners fare in a regular school setting in Sweden, where there is limited knowledge of who the gifted are and what their particular needs are. A wide database search (Google Scholar, search made on July 18, 2008) using the keywords "gifted + regular + school" provided 79,200 articles, books, and papers on the subject. However, the vast majority of this literature assumes the already manifest recognition of the giftedness construct by schools, teachers, and nationwide official policies. In spite of this, there exists more or less consensus amongst scholars that, as a rule, gifted children do not fare well in regular schools if they are unrecognized, ignored, and/or if teachers are unprepared for them. Indeed, what student, irrespective of their degree of ability, would fare well under such circumstances?

Persson (1998) studied 232 teachers unfamiliar with the notion of gifted education in the Swedish comprehensive school system, to chart their commonsense understanding of giftedness, which would potentially indicate how highly gifted children would generally fit in to the school system. He found that the general understanding of someone who is gifted is that of a paragon of virtue: he or she is a leader, a role model for others, a humanitarian, acts as an assistant to the teacher, and in all is an ideal student who always does as told. The emerging picture of a gifted individual in this particular context speaks of myth and misunderstanding. As Mulhern (2003) pointed out in reference to the U.S. school system:

Our educational system has been built on the false assumption that a bright youngster, if no specific provision is made for him, will raise the level of the others in the class. This just doesn't happen. Unless his talent is recognized and provided for by a program that is truly challenging, that talent will simply deteriorate. (p. 112)

There is also a growing body of research suggesting gifted students function best when teachers are philosophically aware, highly professional, and always prepared, and that there are in fact 
certain personality traits facilitating the student-teacher relationship (Baldwin, Vialle, \& Clarke, 2000).

Freeman (1991) is perhaps the scholar who most consistently has addressed school issues on the basis of having followed an original sample of 210 gifted children over many years in England. Although these children were identified by parents as gifted, they went to school prior to the development of any kind of informed or standardized gifted education program in the British school system. These children, however, did go to different types of schools as decided by parents. Some of them were more oriented toward academic elitism than others. Freeman (1991) found that, above all, in the comprehensive schools gifted students' benefit was social rather than intellectual. A unique insight into the experience of being an extremely gifted student in the British school system was also offered by Faludy and Faludy (1996), who described a student's struggle to be recognized in school for what he was and the needs of intellectual stimulation he had. The student was then a promising poet and academically gifted in general, but he was also dyslexic. This complicated matters a great deal for the school system "to make sense" of what to do with him. In her classic longitudinal study of high-IQ children, Hollingworth (1942) observed that:

Children with IQs up to 150 get along in the ordinary course of school life quite well, achieving excellent marks without serious effort. But children above this mental status become almost intolerably bored with school work if kept in lockstep with unselected students of their own age. Children who rise above 170 IQ are liable to regard school with indifference or with positive dislike, for they find nothing in the work to absorb their interest. This condition of affairs, coupled with the supervision of unseeing and unsympathetic teachers, has sometimes led even to truancy on the part of gifted children. (p. 258)

Winner (1996), on the basis of experience and many years of studying the dilemma of the gifted in U.S. public schools, concluded there are mainly four reasons why some form of special education should be offered to the gifted and talented: (1) U.S. schools have low standards; (2) low standards lead to underachievement; (3) academically (as well 
as artistically and musically) gifted children often find that school plays little or no role in the development of their gifts, and (4) gifted children from disadvantaged backgrounds suffer the most from the lack of special educational provisions.

\section{The Swedish School System in Brief}

The Swedish school system, which was the research context for this study, may be outlined as pursuing low standards also, in the sense that its raison d'etre is to bring all students to a minimum level of knowledge and competence; namely the level that is considered to enable all members of society to lead well-functioning lives (Husén, 1979). All resources and all special educational interventions are directed towards achieving this end. The responsibility of the school system ends once students have reached this minimum level. Every student reaching further than the set minimum level is more or less left to fend for him- or herself by systemic default. In addition, the school system is highly egalitarian.

All education throughout the public school system is free of charge. According to the Swedish Education Act, all children should have equal access to education. Education should provide the students with knowledge and, in cooperation with the parents, promote their harmonious development into responsible human beings and members of the community. Consideration should also be given to students with special needs. The curriculum, national objectives, and guidelines for the public education system are laid down by the Swedish government. The academic year normally begins at the end of August and runs to the beginning of June the following year, comprising a total of 40 weeks. The 9-year compulsory school program is for all children between the ages of 7-16 years. Upon the request of the parents, a child may begin school one year earlier, at the age of 6 . Almost all compulsory school students continue on directly to secondary school (equivalent to the U.S. high school) and the majority of these complete this education in 3 years. Secondary education is divided into 17 national 3-year programs. All of these offer a broad general education and basic eligibility to continue studies at the tertiary level. Alongside the national programs are also a number of 
specially designed and individual study programs. Secondary education for the learning disabled offers vocational training in the form of national, specially designed, or individual programs, similar to those of regular secondary education. The national programs for the learning disabled are, however, fewer in number and especially oriented to vocational training. Secondary programs for the learning disabled are 4 years in length.

In this school system there is currently no official policy for gifted education. No actions are therefore taken on behalf of the gifted and talented students ${ }^{1}$. It is of considerable interest to study more systematically how intellectually gifted students experience an egalitarian learning environment entirely void of any gifted education efforts, using the Swedish education system as an example. Observe that this study includes tertiary level education also. This is rare. The assumption is often made that once primary and secondary level have been "endured and survived," a self-actualizing and rewarding time finally begins as the gifted arrives at university. This, however, is by no means a certainty (Arnold, 1995; Robinson, 1997). This study included participants' experiences of their university experiences also. The following research questions were focused on:

- To what degree did participants experience support and understanding by their own families during childhood?

- At what age and how did participants discover that they were gifted and/or different from others?

- What is the experience of understanding and support by an egalitarian education system if intellectually gifted?

- What is the degree of experienced intellectual stimulation in an egalitarian education system if gifted?

- Does the experience of understanding and support as well the degree of intellectual stimulation change over time as the intellectually gifted progress from primary education to secondary education and finally to tertiary education?

Note that questions were also asked about family background. It is well established that family and significant others are important to how a gifted individual develops (Freeman, 2000). To be ignored or

1 For more information in English on the Swedish school system, see http://www.skolverket. $\mathrm{se} / \mathrm{sb} / \mathrm{d} / 190$. 
treated indifferently in education is bad enough, but to be ignored or treated indifferently both by education and at home may potentially be devastating for the gifted individual (cf. Landau, 1990), which certainly is a danger if both the educational system as well as the general culture is egalitarian and shun the notion of individual differences.

\section{Method}

A survey design using an Internet-based questionnaire seemed the most efficient way of reaching the participants. The Swedish branch of Mensa volunteered to participate in the study. In discussing administration with their local representative as well as with the national Mensa Directorate, it was decided that a web-administered questionnaire was the most convenient and, to members, also the most appealing way of answering the questions. Therefore, a questionnaire was constructed using SPSS Dimensions (Statistical Package for the Social Sciences, 2007) and was made available online for a little more than a month (mid-May until beginning of July 2007).

Mensa members were invited to participate by a brief article in Legatus Mensae (Mensa's newsletter for members only) outlining the research and providing the URL to finding the questionnaire online. The Mensa Directorate also sent electronic mail to all members as a reminder.

\section{Research Sample}

The advantage of engaging Mensa is that their membership requirement is an authorized IQ test (most often the Stanford-Binet) with a lowest resulting score of IQ 131 (the 98th percentile or higher). Because there are no standard identification procedures for giftedness in Sweden, and no official recognition of giftedness or gifted education at the present time, the Mensa group represents both an interesting and opportune high-IQ group of intellectually gifted individuals for the study. The criterion for participating was therefore the same as the criterion to become a member of Mensa: Participants have scored an IQ score at or above 131, which, in Gagné's (1993) understanding, qualifies the members of the studied group as at least "moderately 
gifted." There are, however, distinctions made beyond this criterion, which is also reflected in the studied group. Although Gagné proposes to divide IQ-giftedness into the following levels: Basic (IQ 115-117); Moderate (IQ 125-130); Highly (IQ 140-150), and Extremely (IQ $155-160$ ), the choice was made in this study to ask respondents to report percentile scores. Not everyone had been tested by the same test battery and not all were able to report their IQ scores, but all could report their percentile score. Hence, three levels were distinguishable, continuing to use Gagnés nomenclature: 35\% of the group may be characterized as moderately gifted (98th percentile); $58 \%$ as highly gifted (99th percentile) and 7\% as extremely gifted (100th percentile) based on IQ scores alone.

In all, 614 individuals filled in the questionnaire. However, of these, 321 left the questionnaire unfinished (52\%). The reason for this is that a large number of the original participants (52\%) were frustrated with the questions. Some feedback was received from a few of these individuals. The respondents simply felt constrained by the format. They had more to say but could not. Thus, 293 individuals remained and, of these, a further 6 respondents and their provided data had to be eliminated as extreme cases of little serious intent. The elimination was based on the way that these particular participants had responded to the open-ended questions.

Hence, the studied intellectually gifted population of 287 participants had the following characteristics: The youngest participants were 18 years old and the oldest were 68 years old $($ Range $=50)$. The mean age of the group was 34.4 years $(S D=8.8)$. The studied group was heavily skewed towards men. Of the 287 participants, $216(75 \%)$ were men, whereas only $71(25 \%)$ were women. This is a weakness in the design, as men and women, as well as boys and girls, tend to exist under somewhat different conditions in regard to their giftedness and have somewhat different experiences (Freeman, 1998; Kerr, 1994).

Given that the mean age of participants is 34.4 and the age range spans 50 years, do the participants actually reflect on the same type of school considering that both society and the Swedish school system have changed dramatically during this period of time? While curricula and the understanding of teaching and learning certainly have changed considerably, the fundamental egalitarian ethos has not. It has been exceedingly strong since the 1940s, and could be understood, 
at least partly, as the resulting efforts of social and economic engineering enforced by post-war political idealists (cf. Lindbeck, 1997). The oldest participants in the study, therefore, have had much the same experience in the Swedish school system as has the youngest. They have experienced different educational reforms but little change of school culture and fundamental egalitarian values.

Are the participants representative of a typically gifted population? With potentially all Swedish Mensa members at my disposal for the study, the research group would have constituted a population in its own right. As shown, however, at the day of the deadline for participation, a mere 287 individuals chose to complete the questionnaire. So perhaps the question is better phrased asking whether the remaining group was representative of the Swedish Mensa population as a whole. There is no way of knowing in an absolute sense, as a comparison could obviously not be made. However, on the basis of a number of biographical reports of how academically gifted individuals, in Sweden and elsewhere, have often fared in school systems not adapted to their special needs (e.g., Faludy \& Faludy, 1996; Jacoby, 1965; Wais, 2008; White \& Gribbin, 2002), it is fair to argue that the remaining research group is sufficiently representative to be meaningful. The results reported in this study are certainly in line with such previous reports.

\section{Instrumentation}

The questions pertaining to education, family background, and discovery of giftedness were straightforward, exploratory in nature, and original to this study. Questions believed necessary to form a basic understanding of the posed research questions were constructed. They were of three kinds (see the Appendix): multiple choice per variable, scaled statements, and free qualitative responses.

The questionnaire was administered in Swedish. For the purpose of communicating results, however, everything pertaining to the study, including qualitative data, has been translated into English.

The questionnaire was also customarily subjected to a peer evaluation to check feasibility; appropriateness, both ethical and methodological; and content. Two reviewers were asked to comment: one fellow scientist and one exceedingly gifted individual representing 
the population being studied. Remarks and comments were few, but the gifted representative expressed that the questionnaire needed to include more space for written individual comments. This was heeded and additional questions allowing for free verbal responses were added to the instrument.

\section{Data Security and Research Ethics}

Questions of data security and the protection of sensitive information were raised and settled. The resulting database was hosted at a designated, secure, and approved server. Only the researcher and system administrators had access to the database by password. However, in fulfillment of (Swedish) legal stipulations governing the handling of sensitive data, the most important aspect of research ethics in this study is that the submitted questionnaires were in fact truly anonymous. Personal information such as names, codes, social security numbers, or addresses were not requested or in any way recorded.

\section{Manner of Analyses}

The quantitative data were submitted to a simple and descriptive frequency analysis focusing on dispersions within the researched group only.

The qualitative data were derived from participants' free responses, and were submitted to a content analysis stringently following the VSAIEEDC Model (Variation, Specification, Abstraction, Internal verification, External verification, Demonstration, Conclusion; Persson, 2006). This type of pragmatic analysis relies on pattern recognition, as do presumably all qualitative and analytical models. The first step of analysis is to search for variation in the raw data by means of asking whether statements or replies are similar or dissimilar from one another. This procedure is followed by specification; that is, to identity more thoroughly the characteristics of the groups of data that emerged. The data are then abstracted, meaning that in the resulting groups a common denominator is found, which is conceptualized by giving it a label descriptive of the specific group of data. The resulting labels need verifying in order to secure reliability. Verification is internal and external. Internal means that labels need to be feasible 
and logically fit into the emerging larger pattern. External verification, on the other hand, means that the labels can be verified by other published research. Internal verification is always necessary whereas external, partly or entirely, is welcome when available. However, it cannot be a prerequisite, because this would prevent new knowledge from emerging. Rather, further studies will have to confirm some of the resulting findings.

This analytical process can be continued at increasingly higher levels of abstraction if the amount of data available for analysis is large enough: for example, on to a second abstraction level (patterns in patterns) and a third abstraction level (seeking patterns again as resulting from the second-level analysis). For the current study, however, a first abstraction level, patterns only among the raw data, was considered sufficient not to risk reification, given that study was designed as a survey study rather than an interview study. In the following, the resulting labels from the first-level analysis of the qualitative responses made by the participants are italicized. Examples of statements making up each label are provided.

\section{Results}

\section{IQ-Levels, Age, and Means of Discovery/Identification}

The average age of discovery in the group was approximately 15 years of age $(M=15.1)$. The youngest ones could recall events from age 3 and the oldest ones did not realize their giftedness, or at least paid little attention to it, until 50 years of age. There was thus a 47-year span between the youngest and oldest discovery $(S D=10)$. Before and by 10 years of age, $47.5 \%$ had discovered that they were gifted. By 15 years of age, $63.3 \%$ had discovered it. By 20 years of age, $78.8 \%$; by 30 years of age, $91.7 \%$; and by 50 years of age all participants had finally realized that they were gifted. Interestingly, this means that $27 \%$ of the intellectually gifted students left the Swedish school system at age 18 unaware of being gifted. Figure 1 outlines the distribution of age frequencies in the studied sample. 


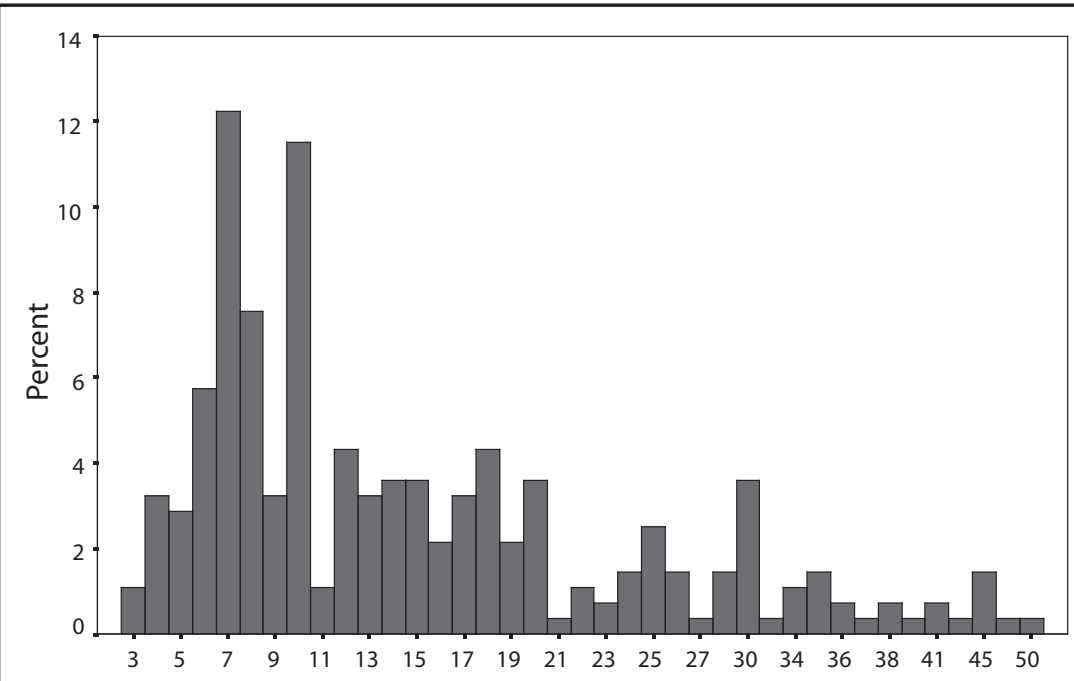

Figure 1. The distribution of respondents' age of discovery $(n=258)$.

\section{Means of Discovery}

For lack of any systematic routines in the Swedish educational system to identify intellectual giftedness, it was necessary to understand how the participants discovered that they were gifted. In a great many cases this meant understanding that they were different from most others in their social context; especially amongst their contemporaries in school. Twenty-nine participants failed to answer the question.

The largest group discovered their giftedness by achievement (34\%), mostly but not exclusively in school. They learned quicker and more efficiently than most others. A large group pointed out that mathematics was their particular talent. Typical statements were: "Easy to learn, it was never an effort"; "I was very good at Maths"; and "I was usually the best one in most subjects at school."

The second largest group realized their giftedness by IQ testing (26\%): Most relied on the Mensa membership test, some on military conscription testing (which every male Swedish citizen has to do by law at age 18), but a number of participants had also found or bought popular tests and tested themselves out of curiosity. 
About 25\% of the respondents realized that they were somehow different by social comparison: comparing themselves to others in their surroundings. Others were slower to think and react than they were, could not understand abstract knowledge as well as they could, and often had a different sort of humor, which rarely amused the intellectual participants of the researched group. "Everyone else seemed so slow," participants observed, and, "I often knew things better than my teachers and made more advanced conclusions than they did."

An interesting fact is that $6 \%$ of the respondents emphasized their predicament of no achievement to be what made them realize that they were different. Unfortunately no achievement also convinced a few that they were "stupid" rather than highly intelligent. Instead of finding satisfaction in achievement when facing compulsory school teaching, they were so bored with school that they gave up trying almost immediately and yielded to doing nothing, a passive attitude that sometimes lasted from school year 1 to year 12 . Several participants reported that they did not do a single assignment for the entire duration of their school years. Typical comments were: "School was too easy. I never did any homework" and "Whenever they said something I did not know, I got it the first time. Unfortunately the teacher then had to repeat it again for everyone else."

A mere $4 \%$ relied on social attribution; that is, they relied on others, often adults, to tell them how talented they were. About 3\% of participants argued that their precocity was their means of discovery. In other words, early development of speech, reading, and writing were regarded as indicators of their giftedness. Finally, $2 \%$ of the respondents claimed that they never noticed anything. There was no discovery whatsoever.

It is not likely that the accounted-for causes for discovery were each and every participant's only means of identifying themselves as gifted or special. These, however, are the means that respondents chose to report, presumably because they stand out as particularly significant to them.

\section{The Support and Understanding of One's Family}

To better outline the family environment and the socioemotional background of the studied group, variables were collapsed into two 


\section{Table 1}

Degree of Experienced Family Support $(\mathrm{N}=287)$

\begin{tabular}{lccc}
\hline Family Situation Growing Up & Separate \% & Collapsed \% \\
\hline $\begin{array}{l}\text { Positive environment } \\
\text { Supportive and understanding }\end{array}$ & 50 & $\Rightarrow$ & 50 \\
Negative environment & 5 & & \\
No support and understanding & 28 & & \\
They were indifferent & 1 & & \\
Parents sometimes ridiculed my talent & 0 & & 50 \\
Siblings sometimes ridiculed my talent & 16 & $\Rightarrow$ & \\
Complex and conflicting & &
\end{tabular}

Note. Separate column includes each rated variable; collapsed column includes variables divided into the two groups. "Complex and conflicting" indicates respondents' choice of more than one variable.

categories: Positive environment ("supportive and understanding") and Negative environment ("no support and understanding"; "they were indifferent"; "parents sometimes ridiculed my talent"; "siblings sometimes ridiculed my talent"). Added to the negative category is "complex and conflicting" where participants had made more than one choice of the provided variables. Any choice made of more than one variable suggests a complex and emotionally difficult situation at times, and choices made that were conflicting such as "supportive and understanding" and "siblings sometimes ridiculed my talent" or "they were indifferent" suggests family inconsistencies that the participants experienced emotionally as a kind of dual world. "Indifference" could perhaps be argued on research technical grounds to be a neutral alternative. However, it is well established in the literature how important active and outspoken support is to a healthy development of identity (e.g., Freeman, 2000). Indifference therefore needs to be understood as negative.

Half of all participants (50\%) were fortunate enough to have had a supportive and understanding home environment, whereas the other half were less fortunate (Table 1).

Participants from an emotionally supportive and understanding family environment typically reported that "parents were inspiring and always helped me"; "I grew up in a family where reflection, 
discussion, and reading were regarded as important"; and "while they considered emotional and social development important, it was also important for them that I do well." However, too much of a good thing might frustrate the child. Two participants reported that they received too much attention: "They were so proud of me it was embarrassing" and "I tired of continuously hearing how clever I was."

The less fortunate participants' experiences at home are more diversified and could be categorized as: double standards (e.g., "father demanded and mother encouraged"; "they showed understanding but no support"; and "at home they were supportive but when elsewhere we were not allowed to say anything indicating how clever we were"); egalitarian stigma (e.g., "they thought it more important to support the intellectually weak" and "I am a normal, intelligent, individual. Not special in anyway. Why the fuss?"); learning disorders (e.g., "they kept complaining until I was tested for Dyslexia" and "since my school grades were never good, my parents mostly considered me stupid"); ignorance of gifted behaviors (e.g., "they were very worried because of my boisterous behavior and lack of respect for others"; "my parents never understood, and they still do not understand"; and "my parents were immigrant working class. They don't know what talent is. Neither do the teachers!"); perceived harassment and discomfort (e.g., "my mother felt threatened by me"; "they could not handle my giftedness, and still can't. Father was indifferent, sometimes envious"; and "they made fun of me for things I could not do so well, such as domestic chores"); and, finally, what could perhaps be termed an alienation from self ("Is a high IQ score a diagnosis that requires support and understanding?").

\section{Support and Understanding in Primary School}

Even though $50 \%$ of the participants were fortunate enough to receive support and understanding at home, not many of them received it at school (i.e., primary school, year 1-9), a situation that quite likely submitted a majority of them to an existence of bewilderment and a difficult search for confirmation and identity. Variables were collapsed here as well, forming two major categories for better overview: an experienced positive school environment and an experienced negative school environment (see Table 2). Only $8 \%$ of the participants 


\section{Table 2}

Degree of Experienced Support in Primary School $(\mathrm{N}=287)$

\begin{tabular}{lccc}
\hline Primary school (year $\mathbf{1}$ to 9) & Separate \% & Collapsed \% \\
\hline Positive environment & 8 & $\Rightarrow$ & 8 \\
$\quad$ Supportive and understanding & & & \\
Negative environment & 24 & & \\
No support and understanding & 28 & \\
They were indifferent & 4 & \\
Students sometimes ridiculed my talent & 1 & \\
Teachers sometimes ridiculed my talent & 35 & $\Rightarrow$ & 92 \\
Complex and conflicting &
\end{tabular}

Note. Separate column includes each rated variable; collapsed column includes variables divided into the two groups. "Complex and conflicting" indicates respondents' choice of more than one variable.

argued that their schooling was mainly positive, whereas an astounding $92 \%$ argued the opposite. Their predicament was often very strongly worded.

While teachers probably did not intend some measures to be taken as punishment, the measures were nevertheless understood as just that and were experienced by a great many participants as a price they had to pay for being high achievers: Punishment by learning detention was relatively common in the studied group (e.g., "If I did my math too quickly, the teacher made me erase everything and start all over again so that I would finish together with the rest"; "to arrive at the correct solution to a given task 'the wrong way' and not the teacher's 'correct' way, was never appreciated"; "I was held back, and was frequently told off for not having done my assignment exactly as I had been told to do it"; and "when weaker students improved the teacher rewarded them. I always scored $100 \%$ and was never rewarded." However, participants also report suspending their own learning completely, sometimes for the entire duration of school. They chose learning detention for social fit (e.g., "who wants to be seen as a bookworm amongst the rest of the class?"; "I had to shut down my brain to adapt to the teacher's level of instruction"; and "I deliberately kept my achievements low so I would fit in." Some participants were definitively perceived as being a threat 
to their teachers (e.g., "my teachers felt threatened by me"; "it always felt like the teachers were bothered by me"; and "I always sought extra work in school but was met by a formidable resistance").

A few teachers apparently decided to make servants out of the gifted children, not assistants. Being an assistant presumes cooperation and that there is a plan to follow decided by the teacher, which also has some meaningfulness. Student and teacher share a responsibility together. Tasks given to the participants in this study, however, were rarely perceived as meaningful, and helping the teacher was hardly a matter of cooperation. Being the teacher's servant meant, for example: "Instead of being given exciting learning assignments I was made to help others" and "my teacher never allowed me to proceed and progress with my own learning, instead I was assigned to grade my fellow classmates' exams."

For some, being gifted also meant being bullied. Being a threat to peers was also reported by the respondents (e.g." "I usually knew more than most others and was bullied for it"; "being a deviant, it was easy to become an outcast"; and "I was harassed and bullied for the most part during the entire duration of school"). Alienation, prompted by complete boredom, beset a majority of the participants in primary school too (e.g., "I was incredibly bored, which resulted in bad grades"; "Everyone in school must obtain passing grades, so teachers completely ignored that some were under-stimulated"; "I did not experience myself as gifted. I thought there was something wrong with me"; and "It was Hell." In comparison, consider Perleth and Heller's (1995) finding that

The older intellectually gifted students prefer working alone and do not like to work cooperatively with students in their classes. This should not be interpreted as saying that the gifted do not want to work with other students; rather, they do not want to work with other members of the class who are usually not as gifted. (p. 100)

However, a few of the participants seem to have enjoyed school most commonly because they met particular teachers, who did indeed take their need for more-than-average intellectual stimulation seriously. But these measures never followed a consistent plan of provision. They were rather spontaneous interventions when needed. 
Participants received partial support and provision (e.g., "The teacher gave me some freedom to take my own initiatives, but could rarely satisfy my need of intellectual stimulation"; "I received a certain degree of support. We had groups in English and Maths divided on the basis of ability: quick learners and slow learners"; "I usually experienced teachers' indifference, with the exception of one teacher in upper primary school, who allowed me to teach instead of her"; and "It was OK, and I felt at times that the demands on me were greater than for others in the class"). A small group of the participants could be characterized as late bloomers (Marjoram, 1986). They were like most other children in school. They even had problems keeping up the pace with the majority of students and also received average grades, but found their skills and confidence either later in the educational system or later in life.

\section{Support and Understanding in Secondary School}

In secondary school, studies became more advanced and more focused on grasping subjects and their main areas more than general societal knowledge, skills, and values. Because students also choose a main direction of their studies and their teachers are subject specialists rather than generalists, it is feasible to assume that gifted students would find their time in secondary school more bearable, even rewarding at times. However, while the research group as a whole did find secondary school somewhat better (23\% reported a largely positive intellectual environment), the large majority, $77 \%$, still felt bored and out of place (see Table 3). Receiving partial support and provision became more common than in primary school, or as one participant expressed it: "Teachers were subject specialists and they were only too happy that someone cared about their particular field." Other comments were: "I was lucky to be assigned to teachers who indeed provided support, some of them were even gifted themselves" and "Whether you were understood and received the support you needed depended on individual teachers." Sadly, though, the ordeal of earlier schooling seemed to have destroyed some participants' trust in education completely. Alienation continued to be a major problem in secondary school: "It was too late when coming to secondary school, you had already adopted a no-achievement attitude"; "Secondary school was even worse, with no interest shown for the gifted at all"; 
Table 3

Degree of Experienced Support in Secondary School $(\mathrm{N}=287)$

\begin{tabular}{lccc}
\hline Secondary school (year $\mathbf{1 0}$ to 12) & Separate \% & Collapsed \% \\
\hline Positive environment & 23 & $\Rightarrow$ & 23 \\
$\quad$ Supportive and understanding & & & \\
Negative environment & 14 & & \\
No support and understanding & 40 & & \\
They were indifferent & 1 & & \\
Students sometimes ridiculed my talent & 0 & & 77 \\
Teachers sometimes ridiculed my talent & 22 & $\Rightarrow$ & 77 \\
Complex and conflicting &
\end{tabular}

Note. Separate column includes each rated variable; collapsed column includes variables divided into the two groups. "Complex and conflicting" indicates respondents' choice of more than one variable.

"I dropped out. I couldn't take it any longer"; and "By this time I had learned well to hide my giftedness." Teacher harassment appears to have been a reality for a few participants: "Teachers gave me lower grades if I had learned and grasped a subject all on my own"; "Half of my teachers thought me a genius and the rest hated me"; and "Free thinking or critical comments for discussion were never appreciated. Instead it was expected you should 'suck up' to the teachers." In a few cases peer harassment was also an issue, demonstrating that the issue of giftedness is also a matter of gender: "The male students in my class tried to suppress me" and "There were students in my class who very actively worked against me. I can only assume they were envious.”

\section{Support and Understanding in Tertiary Education}

Of the participants who went on to university (209 of the 287 participants), some finally found a place where they felt comfortable and motivated: $35 \%$ rated their tertiary level training as mainly positive. Somewhat surprisingly, a majority, $65 \%$, still maintained that even at a higher level of education their experience was mainly negative (see Table 4).

How they fit in, to judge from comments made in addition to the rating, depended on three factors: the chosen university, specific 


\section{Table 4}

Degree of Experienced Support at University Level $(\mathrm{N}=209)$

\begin{tabular}{lccc}
\hline University level & Separate \% & Collapsed \% \\
\hline Positive environment & 35 & \multicolumn{2}{c}{35} \\
$\quad$ Supportive and understanding & 9 & & \\
Negative environment & 39 & & \\
No support and understanding & 1 & & \\
They were indifferent & 1 & & \\
Students sometimes ridiculed my talent & 15 & $\Rightarrow$ & 65 \\
Teachers sometimes ridiculed my talent & &
\end{tabular}

Note. Separate column includes each rated variable; collapsed column includes variables divided into the two groups. "Complex and conflicting" indicates respondents' choice of more than one variable.

departments within that university, and often also on individual teachers in certain departments. One rather striking example was how two respondents experienced similar professional training but at two different, internationally well-respected Swedish colleges of technology: "I went to [A-ville] College of Technology. It was expected that you were talented!" As a comparison, another participant stated: "I was surprised when I started at [B-ville] College of Technology, not to say shocked. To be gifted was not accepted as something positive." Two respondents also appraised a military academy in a similarly opposing manner: "The military identified my giftedness and took extraordinary actions to help and support me," which should be compared to "at the military academy there was no room to go beyond the decided program."

For the more fortunate $35 \%$ of the studied group, commencing higher education was often a matter of finally experiencing a sense of belonging (e.g., "I love the academic world"; "For the first time it was appreciated to be a high achiever"; "Fellow students often gave me compliments"; and "For the first time I met equals"). But the majority of the studied group still struggled with teacher harassment, "Some teachers do not like to be questioned," and continued alienation, "My need of further knowledge was never satisfied where I studied" and 
"They delivered merely required facts with little respect for anything beyond that." Perhaps of some considerable concern was the fact that they suffered a lack of study skills.

A number of respondents reported that because of what they experienced in primary and secondary school, they simply "switched off." They never needed to study or do the assignments, or never cared to do them, because either they already knew the material or they were bored beyond belief. When at university and finding an environment they actually liked, with people and knowledge at a level that finally presented them with a desired challenge, they sometimes failed anyway because they had not developed study techniques and routines by which to learn course texts and do given assignments.

Hence, throughout participants' education, from primary school and to university, the trend is, metaphorically speaking and partly using respondents' choice of words, that they begin in Hell, go through Purgatory, and a few finally arrive in Heaven. In other words, education becomes increasingly more accepting and supporting of the intellectually gifted in secondary and tertiary educational settings. Hostility and indifference towards them decrease, but not for everyone (see Figure 2).

\section{The Degree of Experienced Intellectual Stimulation}

Hand-in-hand with feeling socially accepted and supported goes the experience of learning, a main tenet in for example sociocultural learning theories (e.g., Bronfenbrenner, 1979; Donald, Lazarus, \& Lolwana, 1997; Rogoff, 1990). They are two separate issues, however, but dependent on one another. We need to be both awarded competence by social recognition and experience that we can achieve tasks and goals that we set to, in order to develop a healthy self-image (see Sternberg \& Kolligian, 1990, for an overview). The participants were therefore asked to what degree they thought that they were intellectually stimulated during their time in education. Multiple choices of variables were not possible for this question. The questions, one for each educational level, were scaled using a 5-point Likert scale from all the time to never with a neutral sometimes as the middle possible choice. Also in this case, however, for better overview, possible choices were collapsed into two response categories: Positive stimulation was 


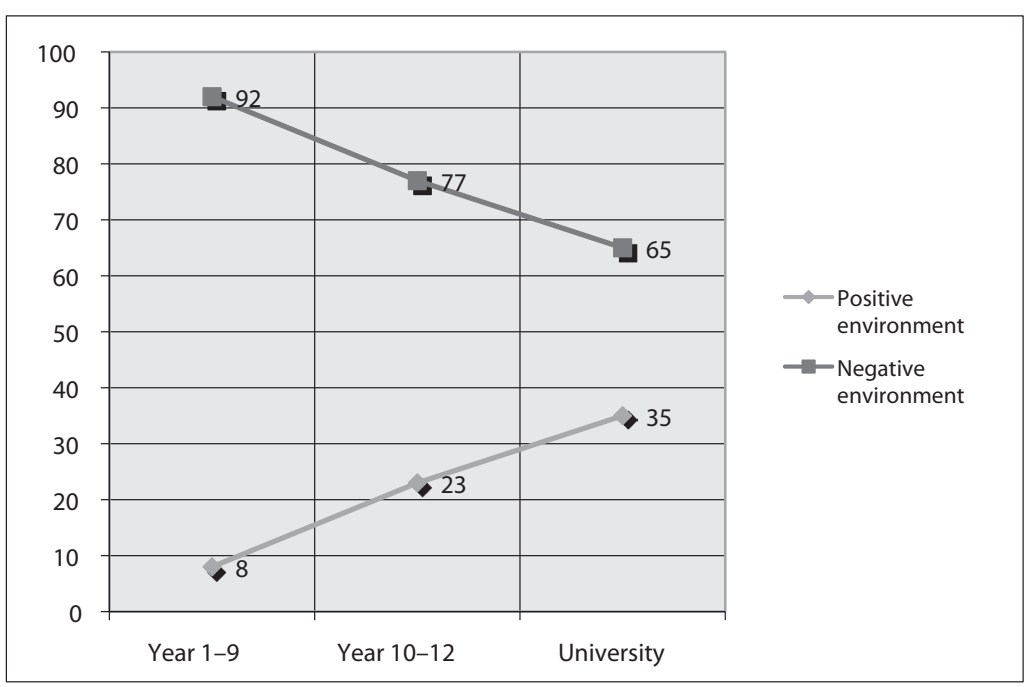

Figure 2. The developing trend of perceived acceptance and support over time, as expressed in educational forms: primary school (year 1-9), secondary school (year 10-12), and tertiary training (university). All values are percentages $(N=287)$.

comprised by always and quite often whereas on occasion expressed a neutral stand, and rarely and never made up negative stimulation. As expected, the development over time reflects the development of support and acceptance (see Figure 3).

In primary school, $76 \%$ claimed they learned very little, whereas $8 \%$ learned more or even a great deal. A larger group of participants, $16 \%$, felt that on the whole school was a rather bland experience and only occasionally stimulated them. In secondary school, stimulation increased: $52 \%$ felt intellectually starved and 17\% were more or less satisfied. The group that took a neutral stand on describing their experience is larger in secondary school (31\%) than in primary school. Once at university, $46 \%$ of the intellectually gifted participants felt that they had finally met the intellectual challenges they had sought and needed for a very long time. However, for reasons discussed earlier, 30\% felt that they remained unchallenged and $24 \%$ experienced tertiary education as fairly dull. 


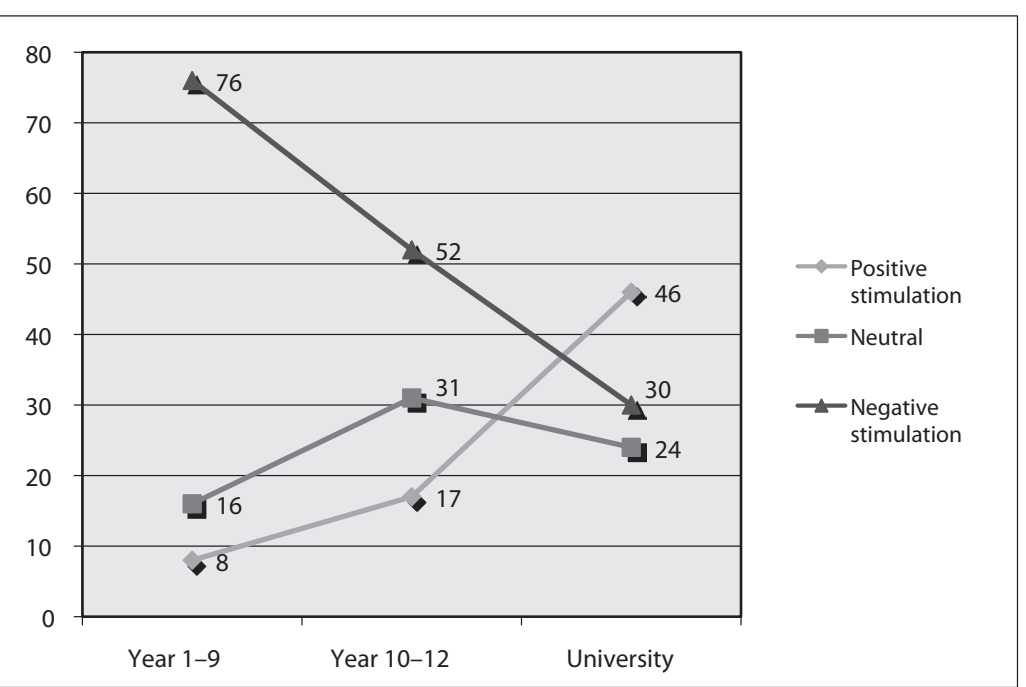

Figure 3. The developing trend of perceived intellectual stimulation over time, as expressed in educational forms: primary school (year 1-9), secondary school (year 10-12), and tertiary training (university). All values are percentages $(N=287)$.

\section{Discussion}

In answer to the research questions, very few of the intellectually gifted participants experienced the Swedish compulsory school (i.e., year 1-9) as a place of understanding and support, nor did they feel that they were intellectually stimulated. The situation for them improved somewhat as they progressed up the educational ladder. According to respondents' comments, the cited and legally stipulated goals of the school system to convey and make possible "respect for the intrinsic value of each person ... the equal value of all people ... to discover their own uniqueness as individuals" (Swedish National Agency for Education, 2006, p. 3) appear valid for every student except for the intellectually gifted student. Instead, $27 \%$ of the research group left the school system (i.e., primary and secondary school) without having been made to understand by their teachers, in positive terms, how unique they were and how valuable their intellectual abilities were. A few teachers only were an exception to the rule for a handful 
of participants. In addition, a majority of the participants suffered ridicule, punishment, and bullying, and were sometimes ordered to assist teachers helping "the weak" without teachers realizing that they were, in fact, creating another group of "weak students" by ignoring, misunderstanding, or even discriminating against their intellectually gifted students (Persson, 1998).

The current Swedish school system has been promoted as inclusive and widely touted as "a school for all." But a school "for all" means for nongifted child ren and children with social, developmental, physical, and learning disabilities only (e.g., Tallberg-Broman, RubinsteinReich, \& Hagerström, 2002). The inclusion also of the gifted into this system is not currently on the agenda, which is unique from both a European and an international perspective (Persson et al., 2000; Soriano de Alencar, Blumen-Prado, \& Castellanos-Simons, 2000; Subhi \& Maoz, 2000; Wu, Cho, \& Munandar, 2000).

Add to this the fact that $50 \%$ of the participants also came from family backgrounds where giftedness was unknown. If known, few families cared very much. In one case, parents did understand that their child was gifted but chose intentionally to ignore it because "they thought it more important to support the intellectually weak." This is not to say that the outcome of such a double-negative situationbeing outsiders in school and lacking understanding and support at home-necessarily leads to an emotional disaster for the intellectually gifted child. Mentors who become significant and instrumental in such children's development can certainly be found elsewhere. But in the situation that there are no such individuals at hand, it is likely that the child will develop problems with self-image and identity, and generally display difficulties in creating and maintaining social relations (see case studies by Landau, 1990).

The results of this study do indeed identify the dangers of uninformed and undifferentiated equity thinking in educational settings in relation to intellectually gifted individuals. In the Swedish research setting, the following problems were identified, echoing concerns raised internationally:

1. Anti-intellectualism: the inherent and largely tacit culture, which does not accept academic prowess, and largely construes it as a type of threat (Howley et al., 1995). 
2. Teachers' lack of knowledge and preparation of how to understand and deal with intellectually gifted individuals. This too is an international problem, especially where systematic teacher training for gifted education is not implemented or available (Baldwin et al., 2000).

3. Systemic failure of recognition, standards, and means for provision are at the root of the problem. A school system needs to have an officially recognized policy and a feasible plan of action. The systemic failure may well be the result of a general ethos of anti-intellectualism, which would also make appropriate teacher training in relation to giftedness problematic at best.

There is very likely a fourth problem area emerging, although this was not an explicit objective of the current study. The provided data, current educational policies, and the knowledge orientation not only of the Swedish educational system but also of youth psychiatry and school psychology, suggest that there are potentially serious mistakes made in clinical settings. While this study shows the tragedy of an academically gifted child in a school system insensitive to his or her needs, showing also that families often are equally void of support (Persson, 2007), then what if the youth health care institutions in highly egalitarian cultures are equally unaware of the needs and characteristics of gifted children? There is anecdotal evidence as reported from insightful special educators and some parents of gifted children to suggest that this is an increasing problem:

4. Psychologists' and psychiatrists' general lack of knowledge and preparation for understanding and dealing with intellectually gifted individuals.

Even if teachers can be made to identify giftedness with some degree of certainty (Hany, 1993) and also taught to design an appropriate and systematic plan to support such children, they will in all likelihood not necessarily have the support of school psychologists and the youth psychiatrists who, void of knowledge and means to act in this particular situation, risk interpreting bored and unruly intelligent children in school as, for example, attention disordered, thus possibly misdiagnosing them as ADHD and ADD (Fitzner \& 
Stark, 2004; Hartnett, Niall-Nelson, \& Rinn, 2004; Webb, Amend, $\&$ Webb, 2005). However, while the void of knowledge of gifted behaviors certainly increases the risk of a diagnosis error, that is not to say that giftedness and attention deficit disorders cannot coexist, although this is currently a matter of debate and some controversy (Antshel et al., 2007).

In conclusion, perhaps one of the more disturbing results of this study is the finding that there were teachers at all levels of the education system who appear to have punished gifted behavior. Such teachers are likely to have felt threatened when opposed, and in response forced students into submission. One student finished too quickly, but was made to erase all the answers just to finish together with the rest of the class, a completely unreasonable measure for a teacher to take. This behavior, on the other hand, may be understood on sociobiological grounds as a simple threat not so much to the order in a classroom, but a threat to the teacher's self-esteem and position of authority (Persson, 2008).

Several school reforms have taken place since the international peace negotiator and former Swedish Prime Minister Olof Palme served as Minister of Education. His directions for the Swedish School System, in the light of this study, appears to still be intact. In publicly addressing school students in the late 1960s, he argued, that "you do not go to school to achieve anything personally, but to learn how to function as members of a group" (as quoted by Huntford, 1972, p. 204). Individual academic achievement and prowess is still a controversial issue. It is somewhat surprising that a nation priding itself with presenting to the world the most prestigious recognition of giftedness of them all, the Nobel Prize, does not encourage intellectual prowess in its educational system. In fact, by system, culture, and knowledge orientation, the current Swedish school system more often suppresses intellectual prowess effectively, even to the extent that many gifted students, especially at primary level, all too frequently become victims of the system causing problems lasting many years beyond school and university (Persson, 2007). A few participants in this study were fortunate and found understanding teachers and mentors in the educational system at all levels, but most had to struggle to endure it. Many simply gave up their efforts altogether. A few reported that when they finally arrived at what seemed exactly what they wanted at a tertiary 
level, they failed anyway, for they knew not how to study when they needed it the most.

Sweden, and to an extent also Norway and Denmark, stand alone in completely refusing their intellectually gifted citizens special provision for the time being. It prompts the question of what the political alternative is in securing a continued future welfare society, when, as German minister of education Dorothé Wilms (1986) publicly stated two decades ago:

No country, which wishes to secure the future of its citizens can, or even may, afford to leave undetected and unsupported a major part of the intellectual and creative abilities of its people. Every society wanting to prosper and meet the challenges of the future, has to rely on a high level of achievement in all its citizens. (pp. 16-17)

\section{References}

Antshel, K. M., Faraone, S. V., Stallone, K., Nave, A., Kaufmann, F. A., . . B Biederman, J. (2007). Is Attention Deficit Hyperactivity Disorder a valid diagnosis in the presence of high IQ? Results from the MGH Longitudinal Family Studies of ADHD. Journal of Child Psychology and Psychiatry, 48, 687-694.

Arnold, K. D. (1995). Lives of promise: What became of high school valedictorians? San Francisco, CA: Jossey-Bass.

Baldwin, A. Y., Vialle, W., \& Clarke, C. (2000). Global professionalism and perception of teachers of the gifted. In K. A. Heller, F. J. Mönks, R. J. Sternberg, \& R. Subotnik (Eds.), International handbook of giftedness and talent (pp. 549-572). Oxford, UK: Pergamon Press.

Borland, J. H. (2003). The death of giftedness: Gifted education without gifted children. In J. H. Borland (Ed.), Rethinking gifted education (pp. 105-142). New York, NY: Teachers College Press. Bronfenbrenner, U. (1979). The ecology of human development: Experiments by nature and design. Cambridge, MA: Harvard University Press. 
Donald, D., Lazarus, S., \& Lolwana, P. (1997). Educational psychology in social context. Oxford, UK: Oxford University Press.

Englund, T. (2005). The discourse on equivalence in Swedish education policy. Journal of Education Policy, 21, 39-57.

Faludy, T., \& Faludy, A. (1996). A little edge of darkness: A boy's triumph over dyslexia. London, England: Jessica Kingsley.

Fitzner, T., \& Stark, W. (Eds.). (2004). Genial, gestört, gelangweilt? ADHS, Schule und Hochbegabung [Genius, disturbed, bored? ADHD, school and giftedness]. Weinheim, Germany: Beltz.

Freeman, J. (1991). Gifted children growing up. London, England: Cassell.

Freeman, J. (1998). Educating the very able: Current international research. London, England: Ofsted/The Stationary Office.

Freeman, J. (2000). Families: The essential context for gifts and talents. In K. A. Heller, F. J. Mönks, R. J. Sternberg, \& R. Subotnik (Eds.), International handbook of giftedness and talent (pp. 573586). Oxford, UK: Pergamon Press.

Gagné, F. (1993). Constructs and models pertaining to exceptional human abilities. In K. A. Heller, F. J. Mönks, \& A. Harry Passow (Eds.), International handbook of research and development of giftedness and talent (pp. 69-88). Oxford, UK: Pergamon Press.

Hany, E. A. (1993). Methodological problems and issues concerning identification. In K. A. Heller, F. J. Mönks, \& A. Harry Passow (Eds.), International handbook of research and development of giftedness and talent (pp. 209-232). Oxford, UK: Pergamon.

Hartnett, D., Niall-Nelson, J. M., \& Rinn, A. N. (2004). Gifted or ADHD? The possibilities of misdiagnosis. Roeper Review, 26, 73-77.

Hollingworth, L. S. (1942). Children above 180 IQ Stanford-Binet: Origin and development. Yonkers-on-Hudson, NY: World Book.

Howley, C. B., Howley, A., \& Pendarvis, E. D. (1995). Out of our minds: Anti-intellectualism and talent development in American schooling. New York, NY: Teachers College Press.

Huntford, R. (1972). The new totalitarians. New York, NY: Stein and Day.

Husén, T. (1979). The school in question: A comparative study of the school and its future in Western Europe. Oxford, UK: Oxford University Press. 
Jacoby, A. (1965). Senor Kon-Tiki. Boken om Thor Heyerdabl [Mister Kon-Tiki: The book about Thor Heyerdahl]. Stockholm, Sweden: Forum.

Kerr, B. A. (1994). Smart girls: A new psychology of girls, women and giftedness (Rev. ed.). Dayton, OH: Gifted Psychology Press.

Landau, E. (1990). Mut zur Begabung [Courage to be gifted]. Munich, Germany: Ernst Reinhardt Verlag.

Lindbeck, A. (1997). The Swedish experiment. Stockholm, Sweden: SNS.

Marjoram, T. (1986). "Late bloomers"-Provision for able youths and adults in the United Kingdom. In A. J. Cropley, K. K. Urban, H. Wagner, \& W. Wieczerkowski (Eds.), Giftedness: A continuing worldwide challenge (pp. 317-325). New York, NY: Trillium Press.

McDaniel, T. (2002). Mainstreaming the gifted: Historical perspective on excellence and equity. Roeper Review, 24, 112-119.

Mulhern, J. D. (2003). The gifted child in the regular classroom. Roeper Review, 25, 112-116.

Perleth, C., \& Heller, K. A. (1995). The Munich Longitudinal Study of Giftedness. In R. F. Subotnik \& K. D. Arnold (Eds.), Beyond Terman: Contemporary longitudinal studies of giftedness and talent (pp. 77-114). Norwood, NJ: Ablex.

Persson, R. S. (1998). Paragons of virtue: Teachers' conceptual understanding of high ability in an egalitarian school system. High Ability Studies, 9, 181-196.

Persson, R. S. (2006). VSAIEEDC-A cognition-based generic model for qualitative data analysis in giftedness and talent research. Gifted and Talented International, 21(2), 29-37.

Persson, R. S. (2007). The myth of the anti-social genius: A survey study of the socio-emotional aspects of high-IQ individuals. Gifted and Talented International, 22(2), 19-34.

Persson, R. S. (2008). The unwanted gifted and talented: A sociobiological perspective of the societal functions of giftedness. In L. Shavinina (Ed.), International handbook of giftedness (pp. 913924). Dordrecht, NL: Springer Science.

Persson, R. S., Balogh, L., \& Joswig, H. (2000). Gifted education in Europe: Programs, practices, and current research. In K. A. Heller, F. J. Mönks, R. J. Sternberg, \& R. Subotnik (Eds.), International 
handbook of giftedness and talent (pp. 703-734). Oxford, UK: Pergamon Press.

Raina, M. K. (1996). Talent search in the Third World: The phenomenon of calculated ambiguity. New Delhi, India: Vikas.

Robinson, N. M. (1997). The role of universities and colleges in educating gifted undergraduates. Peabody Journal of Education, 72, 217-236.

Rogoff, B. (1990). Apprenticeship in thinking: Cognitive development in social context. New York, NY: Oxford University Press.

Soriano de Alencar, E. M. L., Blumen-Prado, S., \& Castellanos-Simon, D. (2000). Programs and practices for identifying and nurturing giftedness and talent in Latin American countries. In K. A. Heller, F. J. Mönks, R. J. Sternberg, \& R. Subotnik (Eds.), International handbook of giftedness and talent (pp. 817-830). Oxford, UK: Pergamon Press.

Statistical Package for the Social Sciences. (2007). SPSS Dimensions. Chicago, IL: SPSS. Retrieved from http://www.spss.com/ dimensions

Sternberg, R. J., \& Kolligian, J., Jr. (Eds.). (1990). Competence considered. New Haven, CT: Yale University Press.

Subhi, T., \& Maoz, N. (2000). Middle-East region: Efforts, policies, programs and issues. In K. A. Heller, F. J. Mönks, R. J. Sternberg, \& R. Subotnik (Eds.), International handbook of giftedness and talent (pp. 743-754). Oxford, UK: Pergamon Press.

Swedish National Agency for Education. (2006). Curriculum for the compulsory school system, the pre-school class and the leisure centre Lpo94. Stockholm, Sweden: Fritzes. Retrieved from http://www. skolverket.se

Tallberg-Broman, I., Rubinstein-Reich, L., \& Hägerström, J. (2002). Likvärdighet i en skola for alla. Historisk bakgrund och kritisk granskning [Equity in a school for everyone: Historical background and a critical overview]. Stockholm, Sweden: National Agency of Education.

Thompson, E. (1994). Fair enough: Egalitarianism in Australia. Sydney, Australia: University of New South Wales Press.

Wais, M. (2008). Hilfe-ich bin hochbegabt! [Help! I am highly gifted]. Berlin, Germany: Mayer. 
Webb, J. T., Amend, E. R., \& Webb, N. (2005). Misdiagnosis and dual diagnoses of gifted children and adults: ADHD, bipolar, OCD, Asperger's, depression, and other disorders. Scottsdale, AZ: Great Potential Press.

White, M., \& Gribbin, J. R. (2002). Stephen Hawkings: A life in science. Washington, DC: Joseph Henry Press.

Wilms, D. (1986). Patron's opening address. In A. J. Cropley, K. K. Urban, H. Wagner, \& W. Wieczerkowski (Eds.), Giftedness: A continuing worldwide challenge (pp. 16-20). New York, NY: Trillium Press.

Winner, E. (1996). Gifted children. New York, NY: Basic Books.

Wu, W.-T., Cho, S., \& Munandar, U. (2000). Programs, practices for identifying and nurturing giftedness and talent in Asia (outside mainland China). In K. A. Heller, F. J. Mönks, R. J. Sternberg, \& R. Subotnik (Eds.), International handbook of giftedness and talent (pp. 765-778). Oxford, UK: Pergamon Press.

\section{Acknowledgments}

For this research, I am indebted to a number of individuals who have willingly assisted me as well as offered their expert knowledge and experience in both setting up the research as well as with reading and commenting on the reported results. I extend my thanks to Robert Mallander, Erik Aludden, Björn Liljeqvist, and Lars Narvselius, all representing Mensa Sweden. I also wish to acknowledge the input and assistance of Magnus Blom and Johan Malmqvist both at Jönköping University, and of Ray Blakemore, The Netherlands, and Rainer Stratkotter, Canada, both of whom are among the most gifted individuals I have ever met. My sincere thanks. 


\section{Appendix \\ Survey Questions for the SPSS Dimensions Online Questionnaire (Translated from Swedish)}

\section{Demographics}

1 . Which is your gender?

Male $\square$

Female $\square$

2. Which is your age? years

3. Which is your intelligence level (the score you received when tested for the MENSA membership). Please, provide your percentile score.

Percentile score

4. How old were you when you first discovered the effects of your giftedness (high IQ-level)? years

5. How did you notice? Outline briefly below:

\section{Questions on Family and Education}

6. How would you describe your own family's appreciation of your giftedness? (You may tick more than one box.)

Supportive and understanding

Not supportive and not understanding

Indifferent

Parents sometimes made fun of your giftedness

Siblings sometimes made fun of your giftedness 
6.1 Comment briefly

7. How would you describe your experience of being gifted in schoolyear 1 to 9? (You may tick more than one box.)

Supportive and understanding

Not supportive and not understanding

Indifferent

Students sometimes made fun of your giftedness

Teachers sometimes made fun of your giftedness

7.1 Comment briefly

8. How would you describe your experience of being gifted in schoolyear 10 to 12? (You may tick more than one box.)

Supportive and understanding

Not supportive and not understanding

Indifferent

Students sometimes made fun of your giftedness

Teachers sometimes made fun of your giftedness

8.1 Comment briefly 
9. How would you describe your experience of being gifted at university? (You may tick more than one box.)

Supportive and understanding

Not supportive and not understanding

Indifferent

Bullying; students made fun of your giftedness

Bullying: teachers made fun of your giftedness

This question is not applicable

9.1 Comment briefly

10. In your opinion, and from your own experience, does school (year 1-9) in Sweden stimulate the further development of someone gifted?

Yes, always

Quite often

On occasion

Rarely

No, never

10.1 Comment briefly

11. In your opinion, and from your own experience, does school (year 10-12) stimulate the further development of someone gifted?

Yes, always

Quite often

On occasion

Rarely

No, never 
11.1 Comment briefly

12. In your opinion, and from your own experience, does studying at university stimulate the further development of someone gifted?

Yes, always

Quite often

$\square$

On occasion

$\square$

Rarely

$\square$

No, never

This question is not applicable

12.1 Comment briefly 


\section{Meet the Authors}

Don Ambrose is professor of graduate education and acting dean of the College of Education at Rider University in Lawrenceville, NJ; editor of the Roeper Review; and past chair of the Conceptual Foundations Division of the National Association for Gifted Children. He has published several books and numerous journal articles and book chapters, most of which are theoretical syntheses and philosophical analyses based on a wide-ranging, interdisciplinary search for theories, philosophical perspectives, and research findings that challenge, refine, and expand thinking about the development of creative intelligence.

Sumita Chakraborti-Ghosh is an associate professor at Tennessee State University. She has taught courses in gifted education for the past 7 years at Tennessee State University and serves on the Gifted Advisory Board for the Tennessee Department of Education. Her research interest areas are cross-cultural special education, multicultural/bilingual special education, technology in special education, gifted education, inclusive education, and emotional disturbance/ behavior disorders. She is an active advocate for social, cultural, linguistic, and emotional needs of gifted minority populations with the Council for Exceptional Children.

Laurence J. Coleman is Daso Herb Professor of Gifted Education in the Department of Early Childhood, Physical and Special Education at the University of Toledo, OH. A special education teacher who became a teacher educator, he is past editor of the Journal for the Education of the Gifted, coauthor of the book Being Gifted in School: An Introduction to Development, Guidance and Teaching, and recipient of the Distinguished Scholar Award from NAGC. His expertise and professional activities include qualitative inquiry, designing summer programs for the gifted, and creating innovative teacher preparation programs.

Amy Crane is a doctoral student in the Department of Counselor Education, Counseling Psychology, and Rehabilitation Services at 
The Pennsylvania State University. She earned her master's degree from Ball State University and her undergraduate degree from Western Michigan University. Her research interests include: gifted adults, relationship quality, and spirituality.

Tracy L. Cross is the Jody and Layton Smith Professor of Gifted Education at the College of William and Mary. For 9 years he served as the executive director of the Indiana Academy for Science, Mathematics and Humanities, a public residential school for academically gifted adolescents. Dr. Cross has published numerous articles and book chapters, and a coauthored textbook Being Gifted in School: An Introduction to Development, Guidance and Teaching. He is the editor of the Journal for the Education of the Gifted and editor emeritus of the Roeper Review, Gifted Child Quarterly, and the Journal of Secondary Gifted Education.

Thomas P. Hébert is professor of educational psychology in the College of Education at The University of Georgia in Athens, GA, where he teaches graduate courses in gifted education and qualitative research methods. His research interests include social and emotional development of gifted students, culturally diverse gifted students, underachievement, and problems faced by gifted young men.

Laurie A. Hyatt is an assistant professor in the psychology department at Barton College in North Carolina. Until 2003, when she began her doctoral studies at The University of Georgia, she maintained a private practice as a Licensed Professional Counselor in Georgia. She is the author of the self-help book, Tools for Living: Taking Control of Your Life (2001).

Tracy M. Ksiazak is a doctoral candidate in counseling psychology at Ball State University. Her research interests are in social and emotional issues of the gifted, adult giftedness, and gender issues. She will begin a career as assistant professor of psychology at Converse College this August, after completing her predoctoral internship at the University of Illinois Urbana-Champaign Counseling Center. 
Emily Lynne Mofield is a gifted education teacher for Sumner County Schools in White House, TN, and an adjunct instructor at Tennessee State University (TSU). She completed her doctoral studies in curriculum and instruction from TSU in 2008 and holds a master's degree in special education from Vanderbilt University. She teaches graduate courses in special education and research methodology at TSU. Her interests focus on addressing emotional needs of the gifted, reversing underachievement, and developing appropriate curriculum for gifted learners.

Kristin M. Perrone is a professor in the Department of Counseling Psychology at Ball State University and a Licensed Psychologist. She also serves as the director of master's programs in community and mental health counseling at Ball State University. Her research interests include gifted adults, career development, and work-family interface.

Roland S. Persson is a professor of educational psychology at Jönköping University in Sweden. His research focuses widely on giftedness and talent, but with an emphasis on social context and the gifted individual in society. Current aspects within this frame are equity issues, gender, music behavior, and social perception. Dr. Persson is a member of the World Council for Gifted and Talented Children and is a lifetime honorary member of the European Council for High Ability.

Catherine A. Schreiber earned her doctoral degree in educational psychology-gifted and creative education in the College of Education at The University of Georgia in Athens, GA. She is an elementary gifted resource teacher in Henry County Public Schools in Stockbridge, GA. Her research interests include dual exceptionalities, gifted males, and therapeutic adventure.

Angela Tanney is a doctoral student in the Department of Counseling Psychology at Ball State University. She is interested in research on gifted and talented individuals. 
Aarika Vannatter is a doctoral student in the Department of Counseling Psychology at Ball State University. She earned her master's degree from Ball State and her undergraduate degree from Purdue University. In addition to research with gifted adults, her other areas of interest include mood disorders, suicide prevention, counseling with older adults, and trauma response.

Joyce VanTassel-Baska is the Smith Professor Emerita at The College of William and Mary in Virginia where she developed a graduate program and a research and development center in gifted education. Formerly, she initiated and directed the Center for Talent Development at Northwestern University. She has also served as the state director of gifted programs for Illinois, as a regional director of a gifted service center in the Chicago area, as coordinator of gifted programs for the Toledo, $\mathrm{OH}$, public school system, and as a teacher of gifted high school students in English and Latin. Dr. VanTasselBaska has published widely including 27 books and more than 500 refereed journal articles, book chapters, and scholarly reports. Her major research interests are on the talent development process and effective curricular interventions with the gifted.

Stephen $\mathbf{L}$. Wright is an assistant professor in counseling psychology at the University of Northern Colorado. He received his Ph.D. from Ball State University with a specialization in assessment. His research interests are in gifted adults, career development, work-family interface, and attachment. 